\title{
Development of Gene Therapy for Thalassemia
}

\author{
Arthur W. Nienhuis and Derek A. Persons \\ Department of Hematology, Division of Experimental Hematology, St. Jude Children's Research Hospital, \\ Memphis, Tennessee 38105 \\ Correspondence: arthur.nienhuis@stjude.org
}

Retroviral vector-mediated gene transfer into hematopoietic stem cells provides a potentially curative therapy for severe $\beta$-thalassemia. Lentiviral vectors based on human immunodeficiency virus have been developed for this purpose and have been shown to be effective in curing thalassemia in mouse models. One participant in an ongoing clinical trial has achieved transfusion independence after gene transfer into bone marrow stem cells owing, in part, to a genetically modified, dominant clone. Ongoing efforts are focused on improving the efficiency of lentiviral vector-mediated gene transfer into stem cells so that the curative potential of gene transfer can be consistently achieved.

$T^{\text {he }}$ he development of gene transfer for the treatment of thalassemia has been a goal for more than three decades (Mercola and Cline 1980). The anticipated targets for gene transfer are hematopoietic stem cells (Naldini 2011; Rivière et al. 2012). Stem and progenitor cells are to be harvested from patient bone marrow or peripheral blood following cytokine mobilization, purified by immunoselection, transduced, and returned to the patient (Fig. 1). Various types of vectors have been considered for gene transfer into stem cells, with integrating retroviruses being the leading candidate. Recently, one participant in an ongoing gene transfer trial for severe $\beta$-thalassemia has achieved clinical benefit with elimination of his transfusion requirement (Cavazzana-Calvo et al. 2010).

Overall, the field of gene therapy evolved slowly over the last three decades (Weatherall 1988). In 1995, the NIH Director convened a panel of experts to evaluate the field (Orkin and Motulsky 1995). Numerous, early clinical trials had been unsuccessful and uninformative. The panel, while noting that well-designed clinical trials are necessary to advance a new therapy, concluded that the methodology of gene transfer had not yet evolved to justify widespread attempts at clinical trials. Proof of efficacy in relevant preclinical models was judged to be necessary before attempting additional clinical trials. Although some academic investigators remained committed to preclinical research and ultimately to clinical trials, commercial interest declined, and there was a general sense of pessimism that pervaded the field.

\section{SUCCESSFUL GENE THERAPY FOR IMMUNODEFICIENCIES}

Success initially came with the report of ex vivo gene therapy trials of gene transfer into hematopoietic stem cells performed in patients with

Editors: David Weatherall, Alan N. Schechter, and David G. Nathan

Additional Perspectives on Hemoglobin and Its Diseases available at www.perspectivesinmedicine.org

Copyright (C) 2012 Cold Spring Harbor Laboratory Press; all rights reserved; doi: 10.1101/cshperspect.a011833

Cite this article as Cold Spring Harb Perspect Med 2012;2:a011833 
A.W. Nienhuis and D.A. Persons

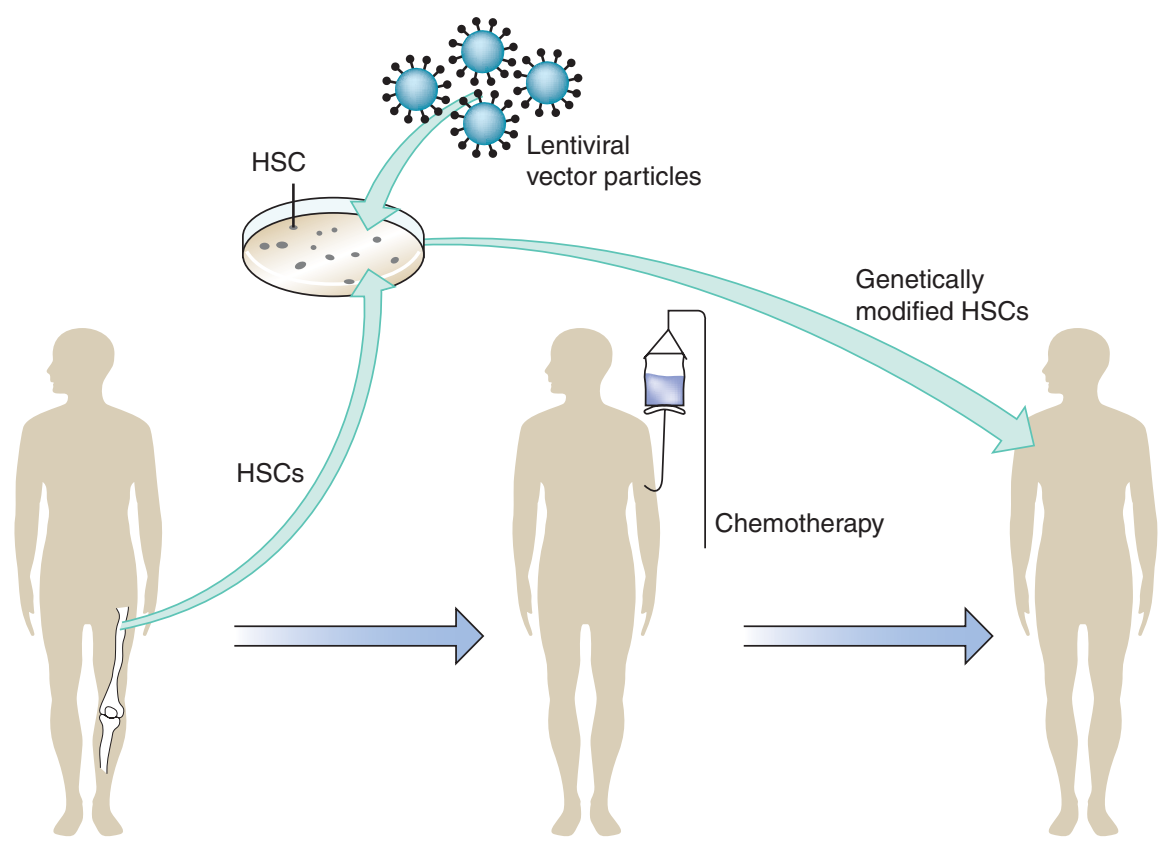

Figure 1. Gene therapy procedures: Cells were collected from the bone marrow of a patient with $\beta$-thalassemia (Cavazzano-Calvo et al. 2010). After purification, the hematopoietic stem cells (HSCs) were maintained in culture for $34 \mathrm{~h}$. Lentiviral vector particles containing a functional $\beta$-globin gene were added, and culture was continued for $18 \mathrm{~h}$. The patient underwent chemotherapy to eradicate the remaining HSCs and make room for the genetically modified cells. The transduced HSCs were then transplanted into the patient by infusion into a peripheral vein. (Adapted from Persons 2010; reprinted, with permission, from the author.)

severe combined immunodeficiency (SCID) secondary to deficiency in the common $\gamma$-chain (X-SCID) (Hacein-Bey-Abina et al. 2002, 2010; Gaspar et al. 2004, 2011b) or adenosine deaminase deficiency (ADA-SCID) (Aiuti et al. 2002, 2009; Gaspar et al. 2011b). Gene-corrected lymphoid cells in these disorders have a growth advantage compared with uncorrected cells and fully repopulate the lymphoid tissues. Gammaretroviral vectors, based on a mouse tumor virus, were used with the coding sequences for the missing protein encoded by a cDNA under the control of the enhancer/promoter elements in the long terminal repeats (LTRs). This initial experience with successful gene therapy has recently been reviewed (Naldini 2011; Rivière et al. 2012). Twenty patients with X-SCID and 40 patients with ADA deficiency have undergone the gene transfer procedure. Generally, the procedure has been successful with recovery of lymphoid elements and correction of the immuno- deficiency, although the procedure has failed in a few older patients with ADA deficiency (Thrasher et al. 2005; Gaspar et al. 2011a). A similar vector was used to treat three individuals with chronic granulomatous disease (CGD) (Ott et al. 2006). Although clinical improvement occurred in two patients initially, complications - to be described below—limited the overall outcome. Recently, a successful gene therapy trial has also been reported for Wiskott-Aldrich syndrome (WAS), with 10 participants showing evidence of clinical improvement (Boztug et al. 2010; Braun et al. 2011; C Klein, pers. comm.). These trials provided proof-of-principle that stem cell-targeted gene transfer can achieve a therapeutic benefit.

The gene therapy trials that used a gammaretroviral vector with intact LTRs have been complicated by insertional mutagenesis and proto-oncogene activation (Hacein-Bey-Abina et al. 2003, 2008; Howe et al. 2008). Five of the 
20 participants in the trials for X-SCID have developed T-cell leukemia. Recently, four of the 10 participants in the trial for WAS have also developed leukemia (Braun et al. 2011; C Klein, pers. comm.). Three patients with CGD developed myelodysplastic syndrome, and one has died of acute myeloid leukemia (Stein et al. 2010). Although the risk of insertional mutagenesis with proto-oncogene activation was recognized when the trials were initiated, this complication was not observed in murine models or in large animal studies over the years (Kiem et al. 2004; Nienhuis et al. 2006). Only one monkey developed myeloid leukemia $5 \mathrm{yr}$ after the gene transfer procedure, thought secondary to vector-mediated inactivation of an anti-apoptotic gene (Seggewiss et al. 2006).

Studies of the pattern of vector integration in patients from the gene therapy trials has uncovered a skewed pattern with preferential integration near or within transcriptionally active genes (Cattoglio et al. 2007; Deichmann et al. 2007, 2011; Schwarzwaelder et al. 2007; Biasco et al. 2012). Remarkably, the majority of patients with leukemia in both the X-SCID and WAS trials had an insertion near or within the LM02 gene, suggesting that its activation was the initiating event in the development of leukemia (Hacein-Bey-Abina et al. 2003, 2008; Schwarzwaelder et al. 2007; Braun et al. 2011; C Klein, pers. comm.). Integrations in the CGD patients were found in the MDS-EVI1, PRDM1, and SETB1 loci (Stein et al. 2010). None of the patients with ADA deficiency has developed leukemia despite vector integration near or within proto-oncogenes including the LM02 gene (Aiuti et al. 2007). The basis for the different outcomes for X-SCID versus ADA-SCID is not understood. A recent review discusses the various possibilities (Shaw and Kohn 2011).

\section{POTENTIALLY SAFER INTEGRATING RETROVIRAL VECTORS}

The occurrence of leukemia in the trials for XSCID, WAS, and CGD has prompted a search for safer vectors, as recently reviewed comprehensively (Wu and Dunbar 2011; Cooray et al. 2012). A self-inactivating (SIN) design involves removal of the enhancer/promoter from the $3^{\prime}$ LTR. During retroviral integration, a portion of the $5^{\prime}$ LTR is copied from the $3^{\prime}$ LTR so that both LTRs lack the enhancer/promoter in the integrated SIN vector genome, thereby reducing the risk for proto-oncogene activation (Yu et al. 1986; Zufferey et al. 1998). The SIN design requires the use of an internal promoter, either retroviral or cellular, to achieve expression of the therapeutic transgene. A SIN design has been applied to deriving a gammaretroviral vector that is now in clinical trials for X-SCID in the United States and Europe (Thornhill et al. 2008). Success in the first patient treated with the new vector (Pai et al. 2011) was reported at the most recent meeting of the American Society of Hematology.

Another modification designed to improve safety is the incorporation of an insulator element into the vector. The insulator element is usually placed in the $3^{\prime}$ LTR of a SIN vector so that it is copied over into the $5^{\prime}$ LTR upon vector integration, resulting in flanking of the transgene with insulator elements (Emery 2011; Cooray et al. 2012). The most well studied of insulator elements is that located in the $5^{\prime}$ hypersensitive site 4 (HS4) of the chicken $\beta$-globin gene locus (Fig. 2) (Chung et al. 1993, 1997; Giles et al. 2010). This insulator has two separable activities; it protects integrated transgenes from silencing by nearby heterochromatin, a socalled barrier activity, and it also blocks interaction between linked enhancer and promoter elements when located between the two (Recillas-Targa et al. 2002). As a barrier element, the insulator prevents spread of silencing histone modifications into the transcribed locus and CpG methylation of the protected promoter sequences (Pikaart et al. 1998). Experimentally, the erythroid-specific LCR elements included in globin gene lentiviral vectors did not activate the proto-oncogene LM02 in human T-cells as expected (Ryu et al. 2008), and the cHS4 insulator reduced gene activation by LCR elements in human erythroleukemia cells (Ryu et al. 2007).

The activities of HS4 have been mapped to a 275-bp core element, which includes five protein-binding sites as determined by DNase I 
A.W. Nienhuis and D.A. Persons

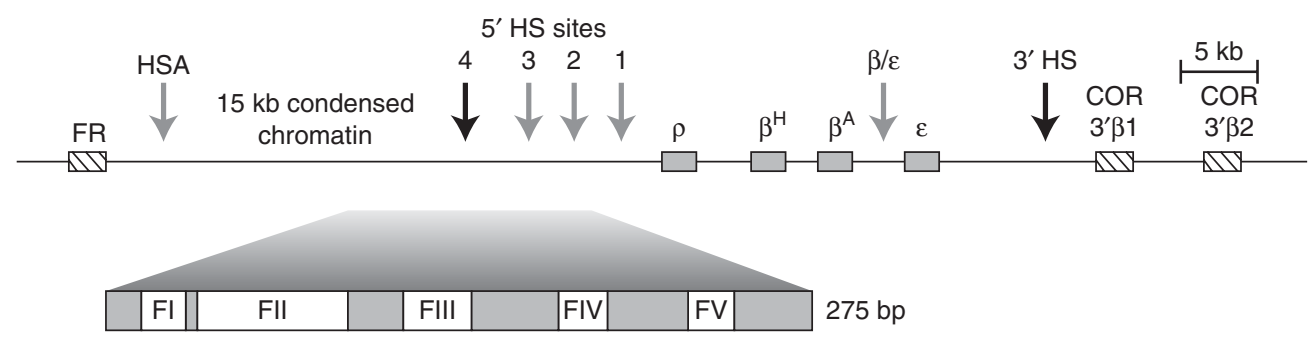

Figure 2. Schematic representation of the chicken $\beta$-globin cluster and surrounding loci. Boxes represent the folate receptor (FR), $\beta$-globin $\left(\rho, \beta^{\mathrm{H}}, \beta^{\mathrm{A}}\right.$, and $\varepsilon$ ), and chicken olfactory receptor (COR) genes (not to scale). (Arrows) DNase I hypersensitive sites. The core of the HS4 element is expanded to show the positions of the five in vitro footprinted sequences (Chung et al. 1997).

footprinting (Fig. 2) (Chung et al. 1997; Giles et al. 2010). The sites have been designated footprint I through footprint V (FI, FII, FIII, FIV, and FV). FII binds the protein CTCF, and this protein is sufficient for enhancer blocking through its interaction with other proteins and intracellular membranes (Bell et al. 1999; Giles et al. 2010; Ghirlando et al. 2012). CTCF and associated proteins anchor the insulator to nuclear structures including the nucleolus, creating a chromatin loop that is thought to inhibit enhancer-promoter interactions. FIV is required for barrier activity and has been shown to bind USF proteins that recruit histone-modifying enzymes associated with transcriptionally active chromatin (West et al. 2004). Such recruitment appears to block encroachment of transcriptionally repressive chromatin into the transcribed region. The remaining protein-binding sites (F1, FIII, and FV) have all been shown to bind the protein VEZF1, which, in the context of recruiting other proteins, protects downstream DNA within the transcribed region from DNA methylation, particularly of promoter elements (Dickson et al. 2010). Overall, insulators are involved in the organization of chromatin domains and in maintaining boundaries, specifically those between repressed chromatin and transcriptionally active chromatin structure (Ghirlando et al. 2012; Kolovos et al. 2012). Other insulators have been considered for vector development, and a limited number have been tested (Emery 2011). For example, a combination of FII from the chicken HS4 and a homologous region from the T-cell receptor, $\alpha /$ $\delta$ BEAD-1 insulator greatly reduced the transforming potential of retroviral vectors (Ramezani et al. 2008).

\section{DEVELOPMENT OF GLOBIN GENE VECTORS}

\section{Gammaretroviral Vectors}

Early studies explored the use of DNA viruses including SV40 (Mulligan et al. 1979), adenovirus (Karlsson et al. 1986), and adeno-associated viral vectors (Walsh et al. 1992; Maina et al. 2008) for transfer of globin-encoding sequences. However, integrating gammaretroviral vectors was judged to be potentially more suitable for achieving permanent genetic modification of hematopoietic cells. With evolving knowledge of the $\beta$-globin gene locus, retroviral vectors were constructed that incorporated the natural promoter sequences, the introns, and the $3^{\prime}$-untranslated sequences in an effort to enhance expression (Cone et al. 1987). Transfer of the complete globin gene into murine stem cells could be accomplished, but the level of expression remained relatively low (Cone et al. 1987; Karlsson et al. 1987; Dzierzak et al. 1988; Sadelain et al. 1995).

\section{Locus Control Region}

Only with the discovery of the locus control region (LCR) upstream from the $\beta$-globin gene cluster did it become feasible to design vectors that achieved higher levels of expression. 
The LCR was discovered by virtue of its functional activity in providing copy number-dependent, integration site-independent globin gene expression in erythroid cells in transgenic mice (Grosveld et al. 1987). Four DNase I hypersensitive (HS) sites are distributed over $\sim 20 \mathrm{~kb}$ upstream from the human $\beta$-globin gene locus (Tuan and London 1984; Tuan et al. 1985; Forrester et al. 1987). Each HS site marks a 200- to 400-bp core element of exposed DNA that includes binding sites for many erythroid or ubiquitously expressed transcriptional factors. The LCR is thought to function by forming a folded structure whereby multiple proteins bound to HS sites interact in forming a holocomplex, which by virtue of loop formation is brought into contact with a promoter within a transcription factory within the nucleus, thereby activating that promoter (Palstra et al. 2008; Schoenfelder et al. 2010; Edelman and Fraser 2012).

\section{Gammaretroviral Vectors Continued}

The series of HS sites upstream from the $\varepsilon$-globin gene has been tailored to minimize the size of vectors by focusing on the core, HS elements for use in gene transfer vectors (Plavec et al. 1993; Emery et al. 1998). Unfortunately, these elements often resulted in gammaretroviral vector instability with low titer. Various strategies were attempted to overcome these limitations, but none was fully successful (Novak et al. 1990; Chang et al. 1992; Takekoshi et al. 1995; Ren et al. 1996; Sabatino et al. 2000; Fragkos et al. 2005). Extensive mutagenesis was required to achieve adequate titers with vectors containing multiple HS sites from the $\beta$-globin locus to remove potential splice or polyadenylation sites and to eliminate sequences in the $\beta$-globin gene that were unnecessary and reduced titer (Leboulch et al. 1994). Another approach that gave results that were somewhat encouraging was the screening of many vectors to identify one that gave a fairly high titer despite the presence of multiple HS fragments. However, highly variable expression was found in mouse erythroleukemia cell clones containing the vector that had been selected based on titer (Sadelain et al. 1995). Addition of an insulator improved expression (Emery et al. 2000) as did other modifications designed to increase globin gene expression (Li et al. 1999). Efforts continued through 2002 to adapt gammaretroviral vectors for transfer of a globin gene with high expression (Nicolini et al. 2002; Emory et al. 2002). Such vectors were also tested for their ability either to correct $\beta$-thalassemia in a mouse model (Nishino et al. 2006) or to express an antisickling $\beta$-globin in human cells from patients with sickle cell disease (Oh et al. 2004). Overall, the extensive efforts over nearly two decades to develop gammaretroviral vectors for globin gene transfer had limited success (Ellis and Pannell 2001), and ultimately committed investigators migrated to the use of lentiviral vectors because of the advantages discussed in the next section.

\section{Lentiviral Vectors}

Lentiviral vectors based on the genome of human immunodeficiency virus (HIV) have several inherent advantages for stem cell-targeted gene transfer (Naldini et al. 1996). HIV-based vectors are able to transduce non-mitotic cells because of the ability of the preintegration complex (PIC) to traverse the intact nuclear membrane, a property that is dependent on the inclusion of specific viral sequences within the gene transfer vector (Follenzi et al. 2000; Sirven et al. 2000; Zennou et al. 2000; Cooray et al. 2012). In addition, the PIC of HIV-based vectors persists in the nucleus much longer than the PIC of gammaretroviral vectors, thereby extending the window during which vector integration may occur (Hass et al. 2000). Activation of the quiescent hematopoietic cells to the $\mathrm{G}_{0} /$ $\mathrm{G}_{1}$ phase of the cell cycle is required for lentiviral vector transduction (Uchida et al. 1998; Case et al. 1999; Sutton et al. 1999). Lentiviral vectors can be packaged with a variety of envelope proteins (Naldini and Verma 2000). Historically, the envelope protein from vesicular stomatitis virus (VSV-G) has been used to pseudotype lentiviral vector particles for experimental use. A recent study confirms that particles having the VSV-G envelope protein are superior at transducing $\mathrm{CD}_{3}{ }^{+}$cells relative to the envelope 
proteins of several gammaretroviruses (Kim et al. 2010).

The chicken HS4 insulator has also been tested within the LTRs of a SIN lentiviral globin vector. Its incorporation into the vector may reduce titer (Urbinati et al 2009), but optimization has been found to improve titer and transgene expression (Arumugam et al. 2007; Hanawa et al. 2009). The core 250-bp element of the cHS4 insulator has been extended with sequences immediately downstream (Aker et al. 2007) or with sequences from the $3^{\prime}$ end of the cHS4 fragment (Arumugam et al. 2009) in efforts to improve vector expression. Overall results suggest that the use of chromatin insulators may improve the expression and safety of integrating gene transfer vectors as summarized in a recent review (Emery 2011).

Although gammaretroviral vectors have a predilection to integrate near transcriptional start sites (Wu et al. 2003), HIV-based lentiviral vector genomes are more uniformly distributed throughout transcribed genes (Schröder et al. 2002). Preferential intragenic integration has also been shown for a $\beta$-globin gene vector in human and murine hematopoietic cells (Imren et al. 2004; Ronen et al. 2011). This is only a relative advantage because inactivation of a tumor suppressor gene may occur with intragenic integration. In addition, some lentiviral vector integrations do indeed occur near a transcription start site. Nonetheless, direct comparison in a tumor-prone mouse model suggests that SIN lentiviral vectors with an internal promoter are significantly less genotoxic than standard gammaretroviral vectors with intact LTRs (Montini et al. 2006). Aberrant splicing events are much reduced by use of SIN lentiviral vector design compared with vectors having intact LTRs (Cesana et al. 2012). Recent data also suggest that the lentiviral vector integration profile in preclinical models and in a clinical trial is inherently less oncogenic than that of gammaretroviral vectors (Biffi et al. 2011). However, insertional mutagenesis and gene activation have been documented with lentiviral vectors (Hargrove et al. 2008; Modlich et al. 2009; Montini et al. 2009), which has led to the development of leukemia in a murine model (Heckl et al. 2012). Thus, use of lentiviral vectors will likely mitigate, but not eliminate, the risk of insertional mutagenesis.

HIV-based vectors having a SIN design are in clinical trials for metachromatic leukodystrophy (MLD) (Biffi and Naldini 2007), adrenoleukodystrophy (ALD) (Cartier et al. 2009, 2012), WAS (Galy and Thrasher 2011; Scaramuzza et al. 2012), and indeed for $\beta$-thalassemia (Cavazzana-Calvo et al. 2010). The results in four patients with MLD are particularly striking in that expression of the therapeutic transgene occurred in $>50 \%$ of hematopoietic cells following stem cell transduction and autologous transplantation with major clinical benefit (A Biffi and L Naldini, pers. comm.). Thus, the greater efficiency of gene transfer into stem cells that had been predicted for lentiviral vectors has apparently been achieved in these early clinical trials.

Another advantage of lentiviral vectors is their well-developed mechanism for nuclearto-cytoplasmic transfer of unspliced mRNA, which facilitated the inclusion of globin genes with intact introns, LCR fragments, and insulator elements (May et al. 2000; Pawliuk et al. 2001). Globin vectors were envisioned as potentially being therapeutically useful both for thalassemia and sickle cell disease. Accordingly, an anti-sickling variant (Oh et al. 2004) or the natural $\gamma$-globin gene (Pestina et al. 2009) has been used to facilitate their ultimate use in treatment of sickle cell disease.

\section{Correction of Mouse Models}

Transgenic mouse strains having either severe $\beta$-thalassemia (Ciavatta et al. 1995; Yang et al. 1995) or sickle cell disease (Pászty et al. 1997) have been derived by the standard transgenic and/or homologous recombination methodologies. Globin vectors have been tested for their ability to correct these phenotypes. Quantitative studies using various transgenic mouse strains had suggested that expression of a transgene in $20 \%$ of the erythroid precursors along with achievement of expression at $20 \%$ of the level of the normal $\beta$-globin gene was likely to be sufficient to correct the phenotype of $\beta$-thalassemia intermedia in the mouse model 
(Persons et al. 2001). Similar studies were performed in the sickle mouse model and suggested that $9 \%-16 \% \mathrm{HbF}$ significantly improved the sickle phenotype (Blouin et al. 2000). Collectively, these studies supported the therapeutic potential of available globin gene vectors for correcting hemoglobin disorders.

Several studies have shown that lentiviral vector-mediated globin gene transfer will ameliorate the phenotype of murine thalassemia intermedia (Imren et al. 2002; May et al. 2002; Persons et al. 2003a; Hanawa et al. 2004; Negre et al. 2011). A mouse model of thalassemia major was developed by transplanting adult mice, following lethal irradiation, with fetal liver cells taken from homozygous, $\beta$-globin-null mice. These animals developed severe anemia and massive splenomegaly as well as extramedullary hematopoiesis by $60 \mathrm{~d}$ of age (Rivella et al. 2003). The phenotype could be rescued by lentiviral vector-mediated, globin gene transfer into the fetal liver cells before transplantation. Significant correction of the erythroid phenotype occurred in animals in which $>95 \%$ of the hemoglobin contained a human $\beta$-globin chain (Rivella et al. 2003). Several studies have also documented the ability of lentiviral vectors to ameliorate or correct the phenotype of sickle cell disease in the mouse model (Pawliuk et al. 2001; Levasseru et al. 2003; Perumbeti et al. 2009; Pestina et al. 2009).

\section{Correction of Human Thalassemic Erythroid Cells}

Lentiviral vectors will also correct the phenotype of $\beta$-thalassemia major in cultured erythroid cells derived from patients with this disorder. Production of normal amounts of $\beta$ globin has been achieved in erythroid cultures with correction of ineffective erythropoiesis and a reduction in apoptosis (Puthenveetil et al. 2004). Gene-corrected primitive cells were transplanted into immune-deficient mice, and effective human erythropoiesis was documented 3-4 mo after transplantation (Puthenveetil et al. 2004). A recent study that used cells from a large number of patients provided additional evidence that the $\beta$-thalassemia major pheno- type may be corrected by gene transfer (Roselli et al. 2010). Therapeutic levels of fetal hemoglobin have also been achieved in erythroid progeny of $\beta$-thalassemic CD34 ${ }^{+}$cells after lentiviral vector-mediated $\gamma$-globin gene transfer in a twostage culture system (Fig. 3) (Wilber et al.2011a).

\section{In Vivo Selection}

Of concern with regard to the development of future clinical trials for treatment of severe $\beta$ thalassemia is the level of stem cell transduction that can be achieved. Strategies have been explored to amplify the genetically modified stem cell pool in vivo to increase its contribution to hematopoiesis relative to the contribution of non-transduced stem cells. A dual gene vector encoding $\gamma$-globin with associated LCR elements and a variant methylguanine methyltransferase, driven by a constitutive promoter, has been used to transduce repopulating cells in the mouse model. On initial reconstitution, animals had subtherapeutic levels of $\gamma$-globinexpressing cells, but in vivo drug selection amplified the genetically modified population, leading to correction of the $\beta$-thalassemia intermedia phenotype in the murine model (Persons et al. 2003b; Zhao et al. 2009). Selective amplification of genetically modified cells by drug selection has also been achieved in nonhuman primate models (Larochelle et al. 2009; Beard et al. 2010).

\section{CLINICAL TRIALS FOR SEVERE $\beta$-THALASSEMIA}

Plans for the first clinical trial using a lentiviral vector to transfer a globin gene into bone marrow cells from patients with $\beta$-thalassemia were announced in 2005 (Bank et al. 2005). The lentiviral vector that was used is a self-inactivating variant that included large segments of the $\beta$ locus control region as well as 250-bp core elements from the chicken HS4 insulator in the LTRs (Fig. 4). To date, three participants have been enrolled on the clinical trial, which is open in Paris (Cavazzana-Calvo et al. 2010; P Leboulch, pers. comm.). The vector encodes a mutated adult $\beta$-globin $\left[\beta^{\mathrm{A}}(\mathrm{T} 87 \mathrm{Q})\right]$ that has 
A.W. Nienhuis and D.A. Persons

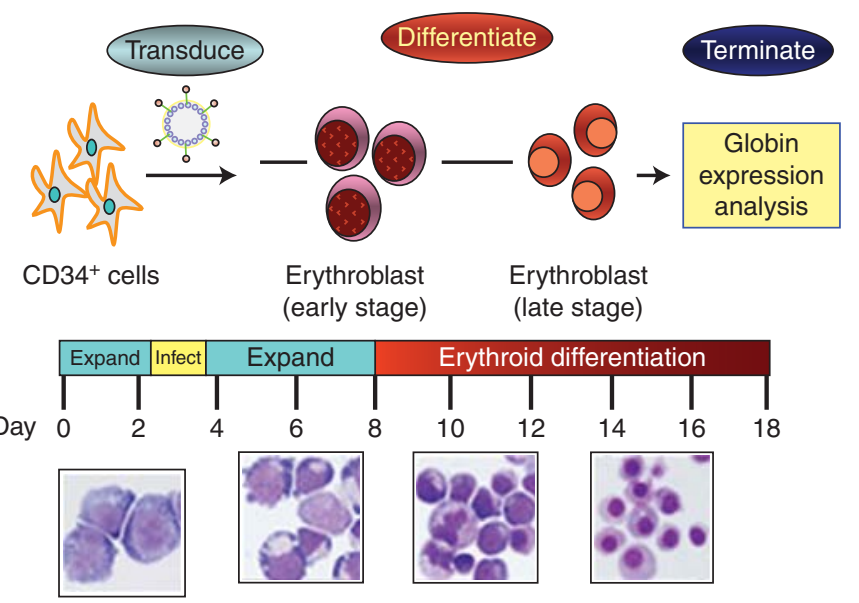

Figure 3. Two-stage culture model of human erythropoiesis. CD34 ${ }^{+}$cells from normal or thalassemic individuals are initiated into culture in medium designed to expand erythroid progenitors. The CD $34^{+}$cells are transduced with a retroviral vector between days 2 and 4 of the expansion phase of the culture. After $8 \mathrm{~d}$, the culture medium is changed to one that favors erythroid differentiation. Full hemoglobinization and often enucleation of the red cells can be achieved, indicating significant maturation. Aliquots were taken at various intervals and at the end of culture to analyze the pattern of hemoglobin production.

anti-sickling properties and can be distinguished from normal adult $\beta$-globin by high performance liquid chromatography. The first patient failed to engraft because the purified $\mathrm{CD} 34^{+}$cells had been compromised technically without relation to the gene therapy vector. The second participant has now been followed for $5 \mathrm{yr}$ after the gene transfer procedure. His clin- ical course is described in detail below. The third patient was transplanted $\sim 2$ mo ago without complication. Hematopoietic reconstitution is ongoing, and the variant $\beta$-globin can be detected in blood reticulocytes.

The second participant in the clinical trial was $18 \mathrm{yr}$ old at the time of treatment and has now been followed for nearly $5 \mathrm{yr}$ following the

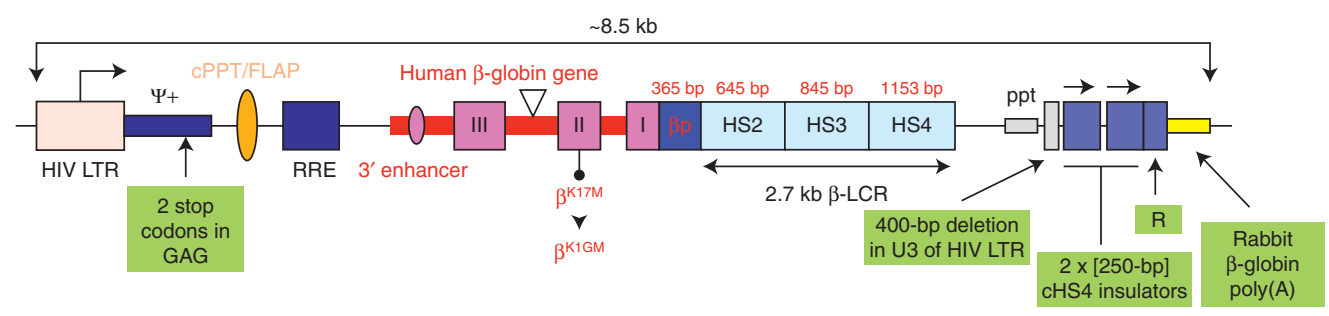

Figure 4. Diagram of the lentiglobin vector showing the $3^{\prime} \beta$-globin enhancer, the 372-bp IVS2 deletion, the $\beta^{\text {A-T87Q }}$ mutation [ACA(Thr) to CAG(Gln)], and the DNase I hypersensitive sites (HS) 2, HS3, and HS4 of the human $\beta$-globin locus control region (LCR). Safety modifications including the two stop codons in the $\Psi+$ signal, the 400-bp deletion in the U3 of the right HIV LTR, the rabbit $\beta$-globin poly(A) signal, and the two 250 bp cHS4 chromatin insulator core fragments are indicated. (HIV LTR) Human immunodeficiency type-1 virus long terminal repeat; $(\Psi+)$ packaging signal; (cPPT/FLAP) central polypurine tract/DNA FLAP; (RRE) Revresponsive element; $(\beta p)$ human $\beta$-globin promoter; $(\mathrm{ppt})$ polypurine tract. Southern blot analysis of transduced cells indicates that up to about one-third of integrated vector copies contain a deletion of one of the cHS4 cores within the right $\mathrm{U} 3$, and about two-thirds of integrated vector copies contain a deletion of one of the cHS4 cores within the left U3 (Cavazzana-Calvo et al. 2010). 
gene transfer procedure (Cavazzana-Calvo et al. 2010). He has severe $\beta^{\mathrm{E}} / \beta^{0}$-thalassemia and began on regular transfusion therapy at age 3 because of severe and poorly tolerated anemia and significant enlargement of the liver and spleen. Splenectomy was performed at age 6 . The participant was conditioned with intravenous $\mathrm{Bu}$ sulfex $(3.2 \mathrm{mg} / \mathrm{kg}$ per day). His transduced bone marrow $\mathrm{CD} 34^{+}$cells were found to have 0.6 vector genomes/transduced cell. The patient received the transduced bone marrow cells in early June of 2007 and was last transfused in early June of 2008. His Hb level has remained between 9 and $10 \mathrm{~g} / \mathrm{dL}$. Approximately onethird of the total hemoglobin is composed of the therapeutic hemoglobin $\mathrm{Hb}-\beta^{\mathrm{A}}$ (T87Q), one-third of which is $\mathrm{HbE}$ and one-third is $\mathrm{HbF}$. The ratio of $\gamma$ to $\beta^{\mathrm{E}}$ globin did not change following the transplant procedure, suggesting that enhancement of $\mathrm{HbF}$ production was not a significant factor in the patient's clinical improvement. The patient has undergone frequent phlebotomies to accelerate the clearance of iron that had accumulated during the several years that he was transfusion dependent.

Insertion site analysis detected a dominant clone in which the vector was integrated into the high-mobility group AT-Hook2 (HMGA2) locus in granulocytes, monocytes, and erythroblasts (Cavazzana-Calvo et al. 2010). This integration site was not found in lymphoid cells. The proportion of genetically modified cells in whole blood increased gradually over time, but the clone having the HMGA2 integration site remained stable at $\sim 2 \%$ total blood cells. Molecular analysis indicated that the HMGA2 gene that had been disrupted by vector integration was actively expressed. All three exons were contained within a truncated RNA product that arose by alternate splicing of the third exon into a cryptic $3^{\prime}$ splice signal located within the insulator core and cleavage/polyadenylation within the adjacent LTR. The disrupted locus encodes a chimeric protein in that the first 83 amino acids are encoded by the three HMGA2 exons fused to 52 amino acids from the readthrough transcript. Missing from this chimeric RNA is the normal 3' untranslated region, which includes two binding sites for LET7 microRNA, which is thought to decrease stability of the transcript within the cytoplasm. Analysis of erythroid cells suggested that the HMGA2 integration site was not particularly favorable for high expression of the transferred globin gene.

A multicenter phase I clinical trial to evaluate globin gene transfer in $\beta$-thalassemia is being developed and led by Michel Sadelain of Memorial Sloan-Kettering Cancer Center (Sadelain et al. 2010). A collaboration between investigators in Greece and in Seattle has also been established to begin preparation for a clinical trial. These investigators have compared mobilization of stem cells with G-CSF alone, mobilization with G-CSF after 1 mo of pretreatment with hydroxyurea to prevent hyperleukocytosis and splenic enlargement, and mobilization with plerixafor. Plerixafor resulted in rapid and effective mobilization in both splenectomized and unsplectomized patients and was well tolerated (Yannaki et al. 2012). We are also planning a trial at St. Jude Children's Research Hospital.

In summary, gene therapy trials for $\beta$-thalassemia are underway or soon to begin. One patient clearly benefited from the gene transfer procedure but in the context of clonal dominance secondary to proto-oncogene activation. This outcome is reminiscent of experience with gammaretroviral gene transfer for the treatment of CGD (Grez et al. 2011). In general, although a clinical benefit has been achieved in several CGD patients, the presence of genetically modified cells has been transient and nearly undetectable in most after a few months following the transplant procedure. Of the 12 patients with CGD who have been treated by gene therapy, only three engrafted with high levels of genemodified cells long term, and in all three cases, clonal expansion was triggered by insertional activation of the proto-oncogene EVI1 (Grez et al. 2011). On the other hand, the outcomes with lentiviral vectors for metachromatic leukodystrophy (A Biffi and L Naldini, pers. comm.) and adrenoleukodystrophy (Cartier et al. 2009, 2012) have generally been more favorable, with persistence of high levels of genetically modified cells for months to years following gene transfer. Only further clinical experience will determine 
A.W. Nienhuis and D.A. Persons

which outcome is most likely for most patients with $\beta$-thalassemia.

\section{STRATEGIES TO IMPROVE STEM CELL-TARGETED GENE TRANSFER}

Compared in Table 1 are the transduction conditions and outcomes in the lentiviral clinical trials conducted to date. Incorporated into the conditions used for transduction for the metachromatic leukodystrophy trial are strategies to reduce proteasome activity (Santoni de Sio et al. 2008, 2009). Prior studies had shown that lentiviral vector-mediated gene transfer into mobilized peripheral blood stem cells is restricted by proteasome activity and that such activity is down-regulated by early active cytokines that enhance transduction. A period of $12 \mathrm{~h}$ rest was incorporated into the transduction protocol to allow cells to recover with reduced proteasome activity, and a proteasome inhibitor was included in the culture medium.

Various other strategies have also been proposed to increase the proliferative potential of primitive cells and to enhance their engraftment. These include transient silencing of PTEN ( phosphatase tensin homolog deleted on chromosome 10) (Kim et al. 2012); inhibition of aldehyde dehydrogenase, which increased radioprotective capacity in the murine model (Muramoto et al. 2010); and addition of nicotinamide, an inhibitor of various ribosylases,

Table 1. Transduction conditions and outcome in lentiviral clinical trials

\begin{tabular}{|c|c|c|c|}
\hline Disease & $\begin{array}{l}\text { Metachromatic } \\
\text { leukodystrophy }\end{array}$ & Adrenoleukodystrophy & $\beta$-Thalassemia \\
\hline Age of patient & & 7 or $7.5 \mathrm{yr}$ & $19 \mathrm{yr}$ \\
\hline Source of CD $34^{+}$cells & $\begin{array}{l}\text { G-CSF mobilization } \\
\text { Peripheral blood }\end{array}$ & $\begin{array}{l}\text { G-CSF mobilization } \\
\text { Peripheral blood }\end{array}$ & Bone marrow \\
\hline Medium & $\mathrm{X}$-vivo 15 & $\mathrm{X}$-vivo 20 & $\mathrm{X}$-vivo 20 \\
\hline $\begin{array}{l}\text { Cell density/viral } \\
\text { density }\end{array}$ & $1 \times 10^{6} \mathrm{~mL}$ & $\begin{array}{l}2.0 \times 10^{6} \mathrm{~mL}^{-1} / \\
5.0 \times 10^{7} \mathrm{~mL}^{-1}\end{array}$ & $\begin{array}{l}2.0 \times 10^{6} \mathrm{~mL}^{-1} / \\
1.1 \times 10^{8} \mathrm{~mL}^{-1}\end{array}$ \\
\hline Cytokines (ng/mL) & $\begin{array}{l}\text { SCF, } 300 \\
\text { TPO, } 100 \\
\text { FlT3L, } 300 \\
\text { IL3, } 60\end{array}$ & $\begin{array}{l}\text { SCF, } 100 \\
\text { TPO, } 100 \\
\text { FlT- } 3,100 \\
\text { IL3, } 60\end{array}$ & $\begin{array}{l}\text { SCF, } 300 \\
\text { TPO, } 10 \\
\text { FlT3L, } 300 \\
\text { IL3, } 100\end{array}$ \\
\hline $\begin{array}{l}\text { Protamine/ } \\
\text { RetroNectin }\end{array}$ & & $4 \mu \mathrm{g} / \mathrm{mL} / 50 \mu \mathrm{g} / \mathrm{mL}$ & $4 \mu \mathrm{g} / \mathrm{mL} / 50 \mu \mathrm{g} / \mathrm{mL}$ \\
\hline Prestimulation & $24 \mathrm{~h}$ & $19 \mathrm{~h} /$ no retro & $34 \mathrm{~h}$ \\
\hline Transduction & $\begin{array}{l}12 \mathrm{~h} \text { wash/rest } \\
12 \mathrm{~h} / 12 \mathrm{~h} \\
\text { proteasome } \\
\text { inhibitor MG132 }\end{array}$ & $16 \mathrm{~h}^{\prime}$ & $18 \mathrm{~h}$ \\
\hline Cells recovered & & $4.6 \times 10^{6}$ or $7.2 \times 10^{6}$ cells $/ \mathrm{kg}$ & $3 \times 10^{8}$ total \\
\hline $\begin{array}{l}\text { Labeling-bulk- } \\
\quad \text { CFU }\end{array}$ & & $50 \%$ or $33 \%$ & $0.6 \mathrm{vg} /$ cell \\
\hline In vivo labeling & $>50 \%$ & $\begin{array}{l}23 \%-13 \%-10 \%^{\mathrm{a}} \\
25 \%-17 \%-10 \%^{\mathrm{a}}\end{array}$ & $\begin{array}{l}\text { 70\% RBCs } \\
\text { 11\% Erythroid } \\
\text { 19\% granulocyte } \\
9 \% \text { B-lymphoid }\end{array}$ \\
\hline Myeloablation & & Cytoxan + busulfan & Busulfan \\
\hline Clinical outcome & $\begin{array}{l}\text { Polyclonal/prevention } \\
\text { of neurological } \\
\text { deterioration }\end{array}$ & $\begin{array}{l}\text { Sustained polyclonal } \\
\text { hematopoiesis/clinical } \\
\text { improvement }\end{array}$ & $\begin{array}{l}\text { Polyclonal with dominant } \\
\text { clone/transfusion } \\
\text { independent }\end{array}$ \\
\hline
\end{tabular}

G-CSF, granulocyte-colony stimulating factor; CFU, colony-forming unit; RBCs, red blood cells.

${ }^{a}$ Values obtained over 16 mo following gene transfer procedure. 
which enhances hematopoietic stem cell activity in the context of ex vivo expansion of functional CD34 ${ }^{+}$cells (Peled et al. 2012). Whether any of these strategies will ultimately be applicable to the in vitro transduction of hematopoietic stem cells with therapeutic vectors remains to be determined. Efforts are also focused on understanding homing and engraftment with the ultimate goal of improving the outcome of the gene transfer procedure (Larochelle et al. 2012).

Rather than transferring a globin gene, another approach would involve the activation of the endogenous $\gamma$-globin genes to compensate for the lack of $\beta$-globin synthesis (Wilber et al. 2011b). Future prospects include the development of targeted vectors with improved efficiency of gene transfer into stem cells (Verhoeyen et al. 2012). Ongoing efforts are also directed toward achieving targeted correction of the causative mutation in repopulating stem cells by homologous recombination (Lombardo et al. 2011). Recently, alternative targets for gene transfer including induced pluripotent stem cells derived from patients' somatic cells have been proposed, although the development of this strategy is far more distant than stem cell-targeted gene transfer (Papapetrou et al. 2011).

\section{CONCLUDING REMARKS}

Three decades of effort to achieve therapeutic globin gene transfer has ultimately proved productive despite periods in which success seemed quite distant. Basic discoveries such as the development of lentiviral vectors and the characterization of the $\beta$-globin LCR were essential milestones on the road to potential success. One patient with a severe form of $\beta$-thalassemia has clearly benefitted, with achievement of transfusion independence albeit with clonal dominance. Ongoing trials for metachromatic leukodystrophy and adrenoleukodystrophy suggest that therapeutic levels of gene transfer into repopulating stem cells can be achieved. Further refinements in the methodology for gene transfer is likely to bring more definite success for the treatment of $\beta$-thalassemia.
Development of Gene Therapy for Thalassemia

\section{ACKNOWLEDGMENTS}

We thank Pat Streich for expert assistance in preparation of the manuscript.

\section{REFERENCES}

Aiuti A, Slavin S, Aker M, Ficara F, Deola S, Mortellaro A, Morecki S, Andolfi G, Tabucchi A, Carlucci F, et al. 2002. Correction of ADA-SCID by stem cell gene therapy combined with nonmyeloablative conditioning. Science 296: 2410-2413.

Aiuti A, Cassani B, Andolfi G, Mirolo M, Biasco L, Recchia A, Urbinati F, Valacca C, Scaramuzza S, Aker M, et al. 2007. Multilineage hematopoietic reconstitution without clonal selection in ADA-SCID patients treated with stem cell gene therapy. J Clin Invest 117: 2233-2240.

Aiuti A, Cattaneo F, Galimberti S, Benninghoff U, Cassani B, Callegaro L, Scaramuzza S, Andolfi G, Mirolo M, Brigida I, et al. 2009. Gene therapy for immunodeficiency due to adenosine deaminase deficiency. $N$ Engl J Med 360: 447-458.

Aker M, Tubb J, Groth AC, Bukovsky AA, Bell AC, Felsenfeld G, Kiem HP, Stamatoyannopoulos G, Emery DW. 2007. Extended core sequences from the cHS4 insulator are necessary for protecting retroviral vectors from silencing position effects. Hum Gene Ther 18: 333-343.

Arumugam PI, Scholes J, Perelman N, Xia P, Yee JK, Malik P. 2007. Improved human $\beta$-globin expression from selfinactivating lentiviral vectors carrying the chicken hypersensitive site-4 (cHS4) insulator element. Mol Ther 15: $1863-1871$.

Arumugam PI, Urbinati F, Velu CS, Higashimoto T, Grimes HL, Malik P. 2009. The $3^{\prime}$ region of the chicken hypersensitive site- 4 insulator has properties similar to its core and is required for full insulator activity. PLoS ONE 4: e6995.

Bank A, Dorazio R, Leboulch P. 2005. A phase I/II clinical trial of $\beta$-globin gene therapy for $\beta$-thalassemia. Ann NY Acad Sci 1054: 308-316.

Beard BC, Trobridge GD, Ironside C, McCune JS, Adair JE, Kiem HP. 2010. Efficient and stable MGMT-mediated selection of long-term repopulating stem cells in nonhuman primates. J Clin Invest 120: $2345-2354$.

Bell AC, West AG, Felsenfeld G. 1999. The protein CTCF is required for the enhancer blocking activity of vertebrate insulators. Cell 98: 387-396.

Biasco L, Baricordi C, Aiuti A. 2012. Retroviral integrations in gene therapy trials. Mol Ther 20: 709-716.

Biffi A, Naldini L. 2007. Novel candidate disease for gene therapy: Metachromatic leukodystrophy. Expert Opin Biol Ther 7: 1193-1205.

Biffi A, Bartolomae CC, Cesana D, Cartier N, Aubourg P, Ranzani M, Cesani M, Benedicenti F, Plati T, Rubagotti E, et al. 2011. Lentiviral vector common integration sites in preclinical models and a clinical trial reflect a benign integration bias and not oncogenic selection. Blood 117: $5332-5339$.

Blouin MJ, Beauchemin H, Wright A, De Paepe M, Sorette M, Bleau AM, Nakamoto B, Ou CN, Stamatoyannopoulos G, 
A.W. Nienhuis and D.A. Persons

Trudel M. 2000. Genetic correction of sickle cell disease: Insights using transgenic mouse models. Nat Med 6: 177-182.

Boztug K, Schmidt M, Schwarzer A, Banerjee PP, Díez IA, Dewey RA, Böhm M, Nowrouzi A, Ball CR, Glimm H, et al. 2010. Stem-cell gene therapy for the Wiskott-Aldrich syndrome. N Engl J Med 363: 1918-1927.

Braun CJ, Boztug K, Schmidt M, Albert MH, Schwarzer A, Paruzynski A, Modlich U, Beier R, Gobring G, Naundorf S, et al. 2011. Efficacy of gene therapy for Wiskott-Aldrich syndrome. Blood 118: 81.

Cartier N, Hacein-Bey-Abina S, Bartholomae CC, Veres G, Schmidt M, Kutschera I, Vidaud M, Abel U, DalCortivo L, Caccavelli L, et al. 2009. Hematopoietic stem cell gene therapy with a lentiviral vector in X-linked adrenoleukodystrophy. Science 326: 818-823.

Cartier N, Hacein-Bey-Abina S, Bartholomae CC, Bougnères $\mathrm{P}$, Schmidt $\mathrm{M}$, Kalle $\mathrm{CV}$, Fischer $\mathrm{A}$, CavazzanaCalvo M, Aubourg P. 2012. Lentiviral hematopoietic cell gene therapy for X-linked adrenoleukodystrophy. Methods Enzymol 507: 187-198.

Case SS, Price MA, Jordan CT, Yu XJ, Wang L, Bauer G, Haas DL, Xu D, Stripecke R, Naldini L, et al. 1999. Stable transduction of quiescent $\mathrm{CD} 34^{+} \mathrm{CD} 38^{-}$human hematopoietic cells by HIV-1-based lentiviral vectors. Proc Natl Acad Sci 96: 2988-2993.

Cattoglio C, Facchini G, Sartori D, Antonelli A, Miccio A, Cassani B, Schmidt M, von Kalle C, Howe S, Thrasher AJ, et al. 2007. Hot spots of retroviral integration in human CD34 ${ }^{+}$hematopoietic cells. Blood 110: 1770-1778.

Cavazzana-Calvo M, Payen E, Negre O, Wang G, Hehir K, Fusil F, Down J, Denaro M, Brady T, Westerman K, et al 2010. Transfusion independence and HMGA2 activation after gene therapy of human $\beta$-thalassaemia. Nature 467: 318-322.

Cesana D, Sgualdino J, Rudilosso L, Merella S, Naldini L, Montini E. 2012. Whole transcriptome characterization of aberrant splicing events induced by lentiviral vector integrations. J Clin Invest 122: 1667-1676.

Chang JC, Liu D, Kan YW. 1992. A 36-base-pair core sequence of locus control region enhances retrovirally transferred human $\beta$-globin gene expression. Proc Natl Acad Sci 89: 3107-3110.

Chung JH, Whiteley M, Felsenfeld G. 1993. A 5 ' element of the chicken $\beta$-globin domain serves as an insulator in human erythroid cells and protects against position effect in Drosophila. Cell 74: 505-514.

Chung JH, Bell AC, Felsenfeld G. 1997. Characterization of the chicken $\beta$-globin insulator. Proc Natl Acad Sci 94: 575-580.

Ciavatta DJ, Ryan TM, Farmer SC, Townes TM. 1995 Mouse model of human $\beta^{0}$ thalassemia: Targeted deletion of the mouse $\beta^{\text {maj }}$ - and $\beta^{\text {min }}$-globin genes in embryonic stem cells. Proc Natl Acad Sci 92: 9259-9263.

Cone RD, Weber-Benarous A, Baorto D, Mulligan RC. 1987. Regulated expression of a complete human $\beta$-globin gene encoded by a transmissible retrovirus vector. Mol Cell Biol 7: 887-897.

Cooray S, Howe SJ, Thrasher AJ. 2012. Retrovirus and lentivirus vector design and methods of cell conditioning. Methods Enzymol 507: 29-57.
Deichmann A, Hacein-Bey-Abina S, Schmidt M, Garrigue A, Brugman $\mathrm{MH}$, Hu J, Glimm H, Gyapay G, Prum B, Fraser CC, et al. 2007. Vector integration is nonrandom and clustered and influences the fate of lymphopoiesis in SCID-X1 gene therapy. J Clin Invest 117: 2225-2232.

Deichmann A, Brugman MH, Bartholomae CC, Schwarzwaelder K, Verstegen MM, Howe SJ, Arens A, Ott MG, Hoelzer D, Seger R, et al. 2011. Insertion sites in engrafted cells cluster within a limited repertoire of genomic areas after gammaretroviral vector gene therapy. Mol Ther 19: 2031-2039.

Dickson J, Gowher H, Strogantsev R, Gaszner M, Hair A, Felsenfeld G, West AG. 2010. VEZF1 elements mediate protection from DNA methylation. PLoS Genet 6: e1000804.

Dzierzak EA, Papayannopoulou T, Mulligan RC. 1988. Lineage-specific expression of a human $\beta$-globin gene in murine bone marrow transplant recipients reconstituted with retrovirus-transduced stem cells. Nature 331: $35-41$.

Edelman LB, Fraser P. 2012. Transcription factories: Genetic programming in three dimensions. Curr Opin Genet Dev 22: $110-114$.

Ellis J, Pannell D. 2001. The $\beta$-globin locus control region versus gene therapy vectors: A struggle for expression. Clin Genet 59: 17-24.

Emery DW. 2011. The use of chromatin insulators to improve the expression and safety of integrating gene transfer vectors. Hum Gene Ther 22: 761-774.

Emery DW, Chen H, Li Q, Stamatoyannopoulos G. 1998. Development of a condensed locus control region cassette and testing in retrovirus vectors for ${ }^{\mathrm{A}} \gamma$-globin. Blood Cells Mol Dis 24: 322-339.

Emery DW, Yannaki E, Tubb J, Stamatoyannopoulos G. 2000. A chromatin insulator protects retrovirus vectors from chromosomal position effects. Proc Natl Acad Sci 97: 9150-9155.

Emery DW, Yannaki E, Tubb J, Nishino T, Li Q, Stamatoyannopoulos G. 2002. Development of virus vectors for gene therapy of $\beta$ chain hemoglobinopathies: Flanking with a chromatin insulator reduces $\gamma$-globin gene silencing in vivo. Blood 100: 2012-2019.

Follenzi A, Ailles LE, Bakovic S, Geuna M, Naldini L. 2000. Gene transfer by lentiviral vectors is limited by nuclear translocation and rescued by HIV-1 pol sequences. Nat Genet 25: 217-222.

Forrester WC, Takegawa S, Papayannopoulou T, Stamatoyannopoulos G, Groudine M. 1987. Evidence for a locus activation region: The formation of developmentally stable hypersensitive sites in globin-expressing hybrids. $\mathrm{Nu}$ cleic Acids Res 15: 10159-10177.

Fragkos M, Anagnou NP, Tubb J, Emery DW. 2005. Use of the hereditary persistence of fetal hemoglobin 2 enhancer to increase the expression of oncoretrovirus vectors for human $\gamma$-globin. Gene Ther 12: 1591-1600.

Galy A, Thrasher AJ. 2011. Gene therapy for the WiskottAldrich syndrome. Curr Opin Allergy Clin Immunol 11: 545-550.

Gaspar HB, Parsley KL, Howe S, King D, Gilmour KC, Sinclair J, Brouns G, Schmidt M, Von Kalle C, Barington T, et al. 2004. Gene therapy of X-linked severe 
combined immunodeficiency by use of a pseudotyped gammaretroviral vector. Lancet 364: 2181-2187.

Gaspar HB, Cooray S, Gilmour KC, Parsley KL, Adams S, Howe SJ, Al Ghonaium A, Bayford J, Brown L, Davies EG, et al. 2011a. Long-term persistence of a polyclonal $\mathrm{T}$ cell repertoire after gene therapy for X-linked severe combined immunodeficiency. Sci Transl Med 3: 97ra79.

Gaspar HB, Cooray S, Gilmour KC, Parsley KL, Zhang F, Adams S, Bjorkegren E, Bayford J, Brown L, Davies EG, et al. 2011b. Hematopoietic stem cell gene therapy for adenosine deaminase-deficient severe combined immunodeficiency leads to long-term immunological recovery and metabolic correction. Sci Transl Med 3: 97ra80.

Ghirlando R, Giles K, Gowher H, Xiao T, Xu Z, Yao H, Felsenfeld G. 2012. Chromatin domains, insulators, and the regulation of gene expression. Biochim Biophys Acta 1819: 644-651.

Giles KE, Gowher H, Ghirlando R, Jin C, Felsenfeld G. 2010. Chromatin boundaries, insulators, and long-range interactions in the nucleus. Cold Spring Harb Symp Quant Biol 75: 79-85.

Grez M, Reichenbach J, Schwäble J, Seger R, Dinauer MC, Thrasher AJ. 2011. Gene therapy of chronic granulomatous disease: The engraftment dilemma. Mol Ther 19: $28-35$.

Grosveld F, van Assendelft GB, Greaves DR, Kollias G. 1987. Position-independent, high-level expression of the human $\beta$-globin gene in transgenic mice. Cell 51: 975-985.

Hacein-Bey-Abina S, Le Deist F, Carlier F, Bouneaud C, Hue C, De Villartay JP, Thrasher AJ, Wulffraat N, Sorensen R, Dupuis-Girod S, et al. 2002. Sustained correction of X-linked severe combined immunodeficiency by ex vivo gene therapy. $N$ Engl J Med 346: 1185-1193.

Hacein-Bey-Abina S, Von Kalle C, Schmidt M, McCormack MP, Wulffraat N, Leboulch P, Lim A, Osborne CS, Pawliuk R, Morillon E, et al. 2003. LMO2-associated clonal $\mathrm{T}$ cell proliferation in two patients after gene therapy for SCID-X1. Science 302: 415-419.

Hacein-Bey-Abina S, Garrigue A, Wang GP, Soulier J, Lim A, Morillon E, Clappier E, Caccavelli L, Delabesse E, Beldjord K, et al. 2008. Insertional oncogenesis in 4 patients after retrovirus-mediated gene therapy of SCIDX1. J Clin Invest 118: 3132-3142.

Hacein-Bey-Abina S, Hauer J, Lim A, Picard C, Wang GP Berry CC, Martinache C, Rieux-Laucat F, Latour S, Belohradsky BH, et al. 2010. Efficacy of gene therapy for X-linked severe combined immunodeficiency. $N$ Engl J Med 363: 355-364.

Hanawa H, Hargrove PW, Kepes S, Srivastava DK, Nienhuis AW, Persons DA. 2004. Extended $\beta$-globin locus control region elements promote consistent therapeutic expression of a $\gamma$-globin lentiviral vector in $\mathrm{mu}-$ rine $\beta$-thalassemia. Blood 104: 2281-2290.

Hanawa H, Yamamoto M, Zhao H, Shimada T, Persons DA. 2009. Optimized lentiviral vector design improves titer and transgene expression of vectors containing the chicken $\beta$-globin locus HS4 insulator element. Mol Ther 17: 667-674.

Hargrove PW, Kepes S, Hanawa H, Obenauer JC, Pei D, Cheng C, Gray JT, Neale G, Persons DA. 2008. Globin lentiviral vector insertions can perturb the expression of
Development of Gene Therapy for Thalassemia

endogenous genes in $\beta$-thalassemic hematopoietic cells. Mol Ther 16: 525-533.

Hass DL, Case SS, Crooks GM, Kohn DB. 2000. Critical factors influencing stable transduction of human $\mathrm{CD} 34^{+}$cells with HIV-1-derived lentiviral vectors. $\mathrm{Mol}$ Ther 2: 71-80.

Heckl D, Schwarzer A, Haemmerle R, Steinemann D, Rudolph C, Skawran B, Knoess S, Krause J, Li Z, Schlegelberger B, et al. 2012. Lentiviral vector induced insertional haploinsufficiency of Ebf1 causes murine leukemia. Mol Ther 20: 1187-1195.

Howe SJ, Mansour MR, Schwarzwaelder K, Bartholomae C, Hubank M, Kempski H, Brugman MH, Pike-Overzet K, Chatters SJ, de Ridder D, et al. 2008. Insertional mutagenesis combined with acquired somatic mutations causes leukemogenesis following gene therapy of SCID-X1 patients. J Clin Invest 118: 3143-3150.

Imren S, Payen E, Westerman KA, Pawliuk R, Fabry ME, Eaves CJ, Cavilla B, Wadsworth LD, Beuzard Y, Bouhassira EE, et al. 2002. Permanent and panerythroid correction of murine $\beta$ thalassemia by multiple lentiviral integration in hematopoietic stem cells. Proc Natl Acad Sci 99: 14380-14385.

Imren S, Fabry ME, Westerman KA, Pawliuk R, Tang P, Rosten PM, Nagel RL, Leboulch P, Eaves CJ, Humphries RK. 2004. High-level $\beta$-globin expression and preferred intragenic integration after lentiviral transduction of human cord blood stem cells. J Clin Invest 114: 953-962.

Karlsson S, Van Doren K, Schweiger SG, Nienhuis AW, Gluzman Y. 1986. Stable gene transfer and tissue-specific expression of a human globin gene using adenoviral vectors. EMBO J 5: 2377-2385.

Karlsson S, Papayannopoulou T, Schweiger SG, Stamatoyannopoulos G, Nienhuis AW. 1987. Retroviral-mediated transfer of genomic globin genes leads to regulated production of RNA and protein. Proc Natl Acad Sci 84: 2411-2415.

Kiem HP, Sellers S, Thomasson B, Morris JC, Tisdale JF, Horn PA, Hematti P, Adler R, Kuramoto K, Calmels B, et al. 2004. Long-term clinical and molecular follow-up of large animals receiving retrovirally transduced stem and progenitor cells: No progression to clonal hematopoiesis or leukemia. Mol Ther 9: 389-395.

Kim YS, Wielgosz MM, Hargrove P, Kepes S, Gray J, Persons DA, Nienhuis AW. 2010. Transduction of human primitive repopulating hematopoietic cells with lentiviral vectors pseudotyped with various envelope proteins. Mol Ther 18: 1310-1317.

Kim I, Kim YJ, Métais JY, Dunbar CE, Larochelle A. 2012. Transient silencing of PTEN in human CD $34^{+}$cells enhances their proliferative potential and ability to engraft immunodeficient mice. Exp Hematol 40: 84-91.

Kolovos P, Knoch TA, Grosveld FG, Cook PR, Papantonis A. 2012. Enhancers and silencers: An integrated and simple model for their function. Epigenetics Chromatin 5: 1.

Larochelle A, Choi U, Shou Y, Naumann N, Loktionova NA, Clevenger JR, Krouse A, Metzger M, Donahue RE, Kang E, et al. 2009. In vivo selection of hematopoietic progenitor cells and temozolomide dose intensification in rhesus macaques through lentiviral transduction with a drug resistance gene. J Clin Invest 119: 1952-1963. 
A.W. Nienhuis and D.A. Persons

Larochelle A, Gillette JM, Desmond R, Ichwan B, Cantilena A, Cerf A, Barrett AJ, Wayne AS, LippincottSchwartz J, Dunbar CE. 2012. Bone marrow homing and engraftment of human hematopoietic stem and progenitor cells is mediated by a polarized membrane domain. Blood 119: $1848-1855$.

Leboulch P, Huang GM, Humphries RK, Oh YH, Eaves CJ, Tuan DY, London IM. 1994. Mutagenesis of retroviral vectors transducing human $\beta$-globin gene and $\beta$-globin locus control region derivatives results in stable transmission of an active transcriptional structure. $E M B O J$ 13: 3065-3076.

Levasseur DN, Ryan TM, Pawlik KM, Townes TM. 2003. Correction of a mouse model of sickle cell disease: Lentiviral/antisickling $\beta$-globin gene transduction of unmobilized, purified hematopoietic stem cells. Blood 102. 4312-4319.

Li Q, Emery DW, Fernandez M, Han H, Stamatoyannopoulos G. 1999. Development of viral vectors for gene therapy of $\beta$-chain hemoglobinopathies: Optimization of a $\gamma$-globin gene expression cassette. Blood 93: 2208-2216.

Lombardo A, Cesana D, Genovese P, Di Stefano B, Provasi E, Colombo DF, Neri M, Magnani Z, Cantore A, Lo Riso P, et al. 2011. Site-specific integration and tailoring of cassette design for sustainable gene transfer. Nat Methods 8: 861-869.

Maina N, Zhong L, Li X, Zhao W, Han Z, Bischof D, Aslanidi G, Zolotukhin S, Weigel-Van Aken KA, Rivers AE et al. 2008. Optimization of recombinant adeno-associated viral vectors for human $\beta$-globin gene transfer and transgene expression. Hum Gene Ther 19: 365-375.

May C, Rivella S, Callegari J, Heller G, Gaensler KM, Luzzatto L, Sadelain M. 2000. Therapeutic haemoglobin synthesis in $\beta$-thalassaemic mice expressing lentivirusencoded human $\beta$-globin. Nature 406: 82-86.

May C, Rivella S, Chadburn A, Sadelain M. 2002. Successful treatment of murine $\beta$-thalassemia intermedia by transfer of the human $\beta$-globin gene. Blood 99: 1902-1908.

Mercola KE, Cline MJ. 1980. The potentials of inserting new genetic information. $N$ Engl J Med 303: 1297-1300.

Modlich U, Navarro S, Zychlinski D, Maetzig T, Knoess S, Brugman MH, Schambach A, Charrier S, Galy A, Thrasher AJ, et al. 2009. Insertional transformation of hematopoietic cells by self-inactivating lentiviral and gammaretroviral vectors. Mol Ther 17: 1919-1928.

Montini E, Cesana D, Schmidt M, Sanvito F, Ponzoni M, Bartholomae C, Sergi Sergi L, Benedicenti F, Ambrosi A, Di Serio C, et al. 2006. Hematopoietic stem cell gene transfer in a tumor-prone mouse model uncovers low genotoxicity of lentiviral vector integration. Nat Biotechnol 24: 687-696.

Montini E, Cesana D, Schmidt M, Sanvito F, Bartholomae CC, Ranzani M, Benedicenti F, Sergi LS, Ambrosi A, Ponzoni M, et al. 2009. The genotoxic potential of retroviral vectors is strongly modulated by vector design and integration site selection in a mouse model of HSC gene therapy. J Clin Invest 119: 964-975.

Mulligan RC, Howard BH, Berg P. 1979. Synthesis of rabbit $\beta$-globin in cultured monkey kidney cells following infection with a SV40 $\beta$-globin recombinant genome. $\mathrm{Na}$ ture 277: $108-114$
Muramoto GG, Russell JL, Safi R, Salter AB, Himburg HA, Daher P, Meadows SK, Doan P, Storms RW, Chao NJ, et al. 2010. Inhibition of aldehyde dehydrogenase expands hematopoietic stem cells with radioprotective capacity. Stem Cells 28: 523-534.

Naldini L. 2011. Ex vivo gene transfer and correction for cellbased therapies. Nat Rev Genet 12: 301-315.

Naldini L, Verma IM. 2000. Lentiviral vectors. Adv Virus Res 55: 599-609.

Naldini L, Blömer U, Gallay P, Ory D, Mulligan R, Gage FH, Verma IM, Trono D. 1996. In vivo gene delivery and stable transduction of nondividing cells by a lentiviral vector. Science 272: 263-267.

Negre O, Fusil F, Colomb C, Roth S, Gillet-Legrand B, Henri A, Beuzard Y, Bushman F, Leboulch P, Payen E. 2011. Correction of murine $\beta$-thalassemia after minimal lentiviral gene transfer and homeostatic in vivo erythroid expansion. Blood 117: 5321-5331.

Nicolini FE, Imren S, Oh IH, Humphries RK, Leboulch P, Fabry ME, Nagel RL, Eaves CJ. 2002. Expression of a human $\beta$-globin transgene in erythroid cells derived from retrovirally transduced transplantable human fetal liver and cord blood cells. Blood 100: 1257-1264.

Nienhuis AW, Dunbar CE, Sorrentino BP. 2006. Genotoxicity of retroviral integration in hematopoietic cells. Mol Ther 13: 1031-1049.

Nishino T, Tubb J, Emery DW. 2006. Partial correction of murine $\beta$-thalassemia with a gammaretrovirus vector for human $\gamma$-globin. Blood Cells, Mol Dis 37: 1-7.

Novak U, Harris EA, Forrester W, Groudine M, Gelinas R. 1990. High-level $\beta$-globin expression after retroviral transfer of locus activation region-containing human $\beta$-globin gene derivatives into murine erythroleukemia cells. Proc Natl Acad Sci 87: 3386-3390.

Oh IH, Fabry ME, Humphries RK, Pawliuk R, Leboulch P, Hoffman R, Nagel RL, Eaves C. 2004. Expression of an anti-sickling $\beta$-globin in human erythroblasts derived from retrovirally transduced primitive normal and sickle cell disease hematopoietic cells. Exp Hematol 32: 461469.

Orkin SH, Motulsky AG. 1995. Report and recommendations of the panel to assess the NIH investment in research on gene therapy. http://www.nih.gov/news/ panelrep.html.

Ott MG, Schmidt M, Schwarzwaelder K, Stein S, Siler U, Koehl U, Glimm H, Kühlcke K, Schilz A, Kunkel H, et al. 2006. Correction of X-linked chronic granulomatous disease by gene therapy, augmented by insertional activation of MDS1-EVI1, PRDM16 or SETBP1. Nat Med 12: 401-409.

Pai S-Y, Notarangelo LD, Harris C, Cattaneo F, Wladkowski M, Armant M, Kao GS, Wielgosz M, Nienhuis AW, Modlich U, et al. 2011. Somatic gene therapy for X-linked severe combined immunodeficiency using a self-inactivating modified gammaretroviral vector results in an improved preclinical safety profile and early clinical efficacy in a human patient. Blood 118: 80 .

Palstra RJ, de Laat W, Grosveld F. 2008. $\beta$-globin regulation and long-range interactions. Adv Genet 61: 107-142.

Papapetrou EP, Lee G, Malani N, Setty M, Riviere I, Tirunagari LM, Kadota K, Roth SL, Giardina P, Viale A, et al. 2011. Genomic safe harbors permit high $\beta$-globin 
transgene expression in thalassemia induced pluripotent stem cells. Nat Biotechnol 29: 73-78.

Pászty C, Brion CM, Manci E, Witkowska HE, Stevens ME, Mohandas N, Rubin EM. 1997. Transgenic knockout mice with exclusively human sickle hemoglobin and sickle cell disease. Science 278: 876-878.

Pawliuk R, Westerman KA, Fabry ME, Payen E, Tighe R, Bouhassira EE, Acharya SA, Ellis J, London IM, Eaves CJ, et al. 2001. Correction of sickle cell disease in transgenic mouse models by gene therapy. Science 294: 2368-2371.

Peled T, Shoham H, Aschengrau D, Yackoubov D, Frei G, Rosenheimer GN, Lerrer B, Cohen HY, Nagler A, Fibach E, et al. 2012. Nicotinamide, a SIRT1 inhibitor, inhibits differentiation and facilitates expansion of hematopoietic progenitor cells with enhanced bone marrow homing and engraftment. Exp Hematol 40: $342-355$.

Persons DA. 2010. Targeting $\beta$-thalassaemia. Nature 467: 277-278.

Persons DA, Allay ER, Sabatino DE, Kelly P, Bodine DM, Nienhuis AW. 2001. Functional requirements for phenotypic correction of murine $\beta$-thalassemia: Implications for human gene therapy. Blood 97: 3275-3282.

Persons DA, Hargrove PW, Allay ER, Hanawa H, Nienhuis AW. 2003a. The degree of phenotypic correction of murine $\beta$-thalassemia intermedia following lentiviralmediated transfer of a human $\gamma$-globin gene is influenced by chromosomal position effects and vector copy number. Blood 101: 2175-2183.

Persons DA, Allay ER, Sawai N, Hargrove PW, Brent TP, Hanawa H, Nienhuis AW, Sorrentino BP. 2003b. Successful treatment of murine $\beta$-thalassemia using in vivo selection of genetically modified, drug-resistant hematopoietic stem cells. Blood 102: 506-513.

Perumbeti A, Higashimoto T, Urbinati F, Franco R, Meiselman HJ, Witte D, Malik P. 2009. A novel human $\gamma$-globin gene vector for genetic correction of sickle cell anemia in a humanized sickle mouse model: Critical determinants for successful correction. Blood 114: 11741185.

Pestina TI, Hargrove PW, Jay D, Gray JT, Boyd KM, Persons DA. 2009. Correction of murine sickle cell disease using $\gamma$-globin lentiviral vectors to mediate highlevel expression of fetal hemoglobin. Mol Ther 17: 245-252.

Pikaart MJ, Recillas-Targa F, Felsenfeld G. 1998. Loss of transcriptional activity of a transgene is accompanied by DNA methylation and histone deacetylation and is prevented by insulators. Genes Dev 12: 2852-2862.

Plavec I, Papayannopoulou T, Maury C, Meyer F. 1993. A human $\beta$-globin gene fused to the human $\beta$-globin locus control region is expressed at high levels in erythroid cells of mice engrafted with retrovirus-transduced hematopoietic stem cells. Blood 81: 1384-1392.

Puthenveetil G, Scholes J, Carbonell D, Qureshi N, Xia P, Zeng L, Li S, Yu Y, Hiti AL, Yee JK, et al. 2004. Successful correction of the human $\beta$-thalassemia major phenotype using a lentiviral vector. Blood 104: 3445-3453.

Ramezani A, Hawley TS, Hawley RG. 2008. Combinatiorial incorporation of enhancer-blocking components of chicken $\beta$-globin $5^{\prime} \mathrm{HS} 4$ and human T-cell receptor $\alpha / \delta$
BEAD-1 Insulators in self-inactivating retroviral vectors reduces their genotoxic potential. Stem Cells 26: 32573266.

Recillas-Targa F, Pikaart MJ, Burgess-Beusse B, Bell AC, Litt MD, West AG, Gaszner M, Felsenfeld G. 2002. Position-effect protection and enhancer blocking by the chicken $\beta$-globin insulator are separable activities. Proc Natl Acad Sci 99: 6883-6888.

Ren S, Wong BY, Li J, Luo XN, Wong PM, Atweh GF. 1996. Production of genetically stable high-titer retroviral vectors that carry a human $\gamma$-globin gene under the control of the $\alpha$-globin locus control region. Blood 87: $2518-$ 2524.

Rivella S, May C, Chadburn A, Rivière I, Sadelain M. 2003. A novel murine model of Cooley anemia and its rescue by lentiviral-mediated human $\beta$-globin gene transfer. Blood 101: 2932-2939.

Rivière I, Dunbar CE, Sadelain M. 2012. Hematopoietic stem cell engineering at a crossroads. Blood 119: 11071116.

Ronen K, Negre O, Roth S, Colomb C, Malani N, Denaro M, Brady T, Fusil F, Gillet-Legrand B, Hehir K, et al. 2011. Distribution of lentiviral vector integration sites in mice following therapeutic gene transfer to treat $\beta$-thalassemia. Mol Ther 19: 1273-1286.

Roselli EA, Mezzadra R, Frittoli MC, Maruggi G, Biral E, Mavilio F, Mastropietro F, Amato A, Tonon G, Refaldi C, et al. 2010. Correction of $\beta$-thalassemia major by gene transfer in haematopoietic progenitors of pediatric patients. EMBO Mol Med 2: 315-328.

Ryu BY, Persons DA, Evans-Galea MV, Gray JT, Nienhuis AW. 2007. A chromatin insulator blocks interactions between globin regulatory elements and cellular promoters in erythroid cells. Blood Cells Mol Dis 39: 221228.

Ryu BY, Evans-Galea MV, Gray JT, Bodine DM, Persons DA, Nienhuis AW. 2008. An experimental system for the evaluation of retroviral vector design to diminish the risk for proto-oncogene activation. Blood 111: $1866-$ 1875.

Sabatino DE, Seidel NE, Aviles-Mendoza GJ, Cline AP, Anderson SM, Gallagher PG, Bodine DM. 2000. Longterm expression of $\gamma$-globin mRNA in mouse erythrocytes from retrovirus vectors containing the human $\gamma$ globin gene fused to the ankyrin-1 promoter. Proc Natl Acad Sci 97: 13294-13299.

Sadelain M, Wang CH, Antoniou M, Grosveld F, Mulligan RC. 1995. Generation of a high-titer retroviral vector capable of expressing high levels of the human $\beta$ globin gene. Proc Natl Acad Sci 92: 6728-6732.

Sadelain M, Rivière I, Wang X, Boulad F, Prockop S, Giardina P, Maggio A, Galanello R, Locatelli F, Yannaki E. 2010. Strategy for a multicenter phase I clinical trial to evaluate globin gene transfer in $\beta$-thalassemia. Ann NY Acad Sci 1202: 52-58.

Santoni de Sio F, Naldini L. 2009. Short-term culture of human $\mathrm{CD} 34^{+}$cells for lentiviral gene transfer. Methods Mol Biol 506: 59-70.

Santoni de Sio FR, Gritti A, Cascio P, Neri M, Sampaolesi M, Galli C, Luban J, Naldini L. 2008. Lentiviral vector gene transfer is limited by the proteasome at 
A.W. Nienhuis and D.A. Persons

postentry steps in various types of stem cells. Stem Cells 26: $2142-2152$.

Scaramuzza S, Biasco L, Ripamonti A, Castiello MC, Loperfido M, Draghici E, Hernandez RJ, Benedicenti F, Radrizzani M, Salomoni M, et al. 2012. Preclinical safety and efficacy of human $\mathrm{CD} 34^{+}$cells transduced with lentiviral vector for the treatment of Wiskott-Aldrich syndrome. Mol Ther doi: 10.1038/mt.2012.23.

Schoenfelder S, Sexton T, Chakalova L, Cope NF, Horton A, Andrews S, Kurukuti S, Mitchell JA, Umlauf D, Dimitrova DS, et al. 2010. Preferential associations between co-regulated genes reveal a transcriptional interactome in erythroid cells. Nat Genet 42: 53-61.

Schröder AR, Shinn P, Chen H, Berry C, Ecker JR, Bushman F. 2002. HIV-1 integration in the human genome favors active genes and local hotspots. Cell 110: 521-529.

Schwarzwaelder K, Howe SJ, Schmidt M, Brugman MH, Deichmann A, Glimm H, Schmidt S, Prinz C, Wissler M, King DJ, et al. 2007. Gammaretrovirus-mediated correction of SCID-X1 is associated with skewed vector integration site distribution in vivo. J Clin Invest 117: 2241-2249.

Seggewiss R, Pittaluga S, Adler RL, Guenaga FJ, Ferguson C, Pilz IH, Ryu B, Sorrentino BP, Young WS III, Donahue RE, et al. 2006. Acute myeloid leukemia is associated with retroviral gene transfer to hematopoietic progenitor cells in a rhesus macaque. Blood 107: 3865-3867.

Shaw KL, Kohn DB. 2011. A tale of two SCIDs. Sci Transl Med 3: 97ps36.

Sirven A, Pflumio F, Zennou V, Titeux M, Vainchenker W, Coulombel L, Dubart-Kupperschmitt A, Charneau P. 2000. The human immunodeficiency virus type- 1 central DNA flap is a crucial determinant for lentiviral vector nuclear import and gene transduction of human hematopoietic stem cells. Blood 96: 4103-4110.

Stein S, Ott MG, Schultze-Strasser S, Jauch A, Burwinkel B, Kinner A, Schmidt M, Krämer A, Schwäble J, Glimm H, et al. 2010. Genomic instability and myelodysplasia with monosomy 7 consequent to EVI1 activation after gene therapy for chronic granulomatous disease. Nat Med 16: $198-204$.

Sutton RE, Reitsma MJ, Uchida N, Brown PO. 1999. Transduction of human progenitor hematopoietic stem cells by human immunodeficiency virus type 1-based vectors is cell cycle dependent. J Virol 73: 649-660.

Takekoshi KJ, Oh YH, Westerman KW, London IM, Leboulch P. 1995. Retroviral transfer of a human $\beta$-globin $/ \delta$-globin hybrid gene linked to $\beta$ locus control region hypersensitive site 2 aimed at the gene therapy of sickle cell disease. Proc Natl Acad Sci 92: 3014-3018.

Thornhill SI, Schambach A, Howe SJ, Ulaganathan M, Grassman E, Williams D, Schiedlmeier B, Sebire NJ, Gaspar HB, Kinnon C, et al. 2008. Self-inactivating gammaretroviral vectors for gene therapy of X-linked severe combined immunodeficiency. Mol Ther 16: 590-598.

Thrasher AJ, Hacein-Bey-Abina S, Gaspar HB, Blanche S, Davies EG, Parsley K, Gilmour K, King D, Howe S, Sinclair J, et al. 2005. Failure of SCID-X1 gene therapy in older patients. Blood 105: 4255-4257.

Tuan D, London IM. 1984. Mapping of DNase I-hypersensitive sites in the upstream DNA of human embryonic $\varepsilon$ - globin gene in K562 leukemia cells. Proc Natl Acad Sci 81: $2718-2722$.

Tuan D, Solomon W, Li Q, London IM. 1985. The " $\beta$-likeglobin" gene domain in human erythroid cells. Proc Natl Acad Sci 82: 6384-6388.

Uchida N, Sutton RE, Friera AM, He D, Reitsma MJ, Chang WC, Veres G, Scollay R, Weissman IL. 1998. HIV, but not murine leukemia virus, vectors mediate high efficiency gene transfer into freshly isolated $\mathrm{G}_{0} / \mathrm{G}_{1}$ human hematopoietic stem cells. Proc Natl Acad Sci 95: 11939-11944.

Urbinati F, Arumugam P, Higashimoto T, Perumbeti A, Mitts K, Xia P, Malik P. 2009. Mechanism of reduction in titers from lentivirus vectors carrying large inserts in the 3'LTR. Mol Ther 17: 1527-1536.

Verhoeyen E, Relouzat F, Cambot M, Costa C, Nègre D, Legrand F, Joubert C, Le Grand R, Cosset FL, Leboulch P, et al. 2012. Stem cell factor-displaying SIV vectors together with a low conditioning regimen allow for longterm engraftment of gene marked autologous hematopoietic stem cells in macaques. Hum Gene Ther 23: $754-768$.

Walsh CE, Liu JM, Xiao X, Young NS, Nienhuis AW, Samulski RJ. 1992. Regulated high level expression of a human $\gamma$-globin gene introduced into erythroid cells by an adeno-associated virus vector. Proc Natl Acad Sci 89: $7257-7261$.

Weatherall DJ. 1988. The slow road to gene therapy. Nature 331: $13-14$.

West AG, Huang S, Gaszner M, Litt MD, Felsenfeld G. 2004. Recruitment of histone modifications by USF proteins at a vertebrate barrier element. Mol Cell 16: 453-463.

Wilber A, Hargrove PW, Kim YS, Riberdy JM, Sankaran VG, Papanikolaou E, Georgomanoli M, Anagnou NP, Orkin SH, Nienhuis AW, et al. 2011a. Therapeutic levels of fetal hemoglobin in erythroid progeny of $\beta$-thalassemic $\mathrm{CD} 34^{+}$cells after lentiviral vector-mediated gene transfer. Blood 117: 2817-2826.

Wilber A, Nienhuis AW, Persons DA. 2011b. Transcriptional regulation of fetal to adult hemoglobin switching: New therapeutic opportunities. Blood 117: 3945-3953.

Wu C, Dunbar CE. 2011. Stem cell gene therapy: The risks of insertional mutagenesis and approaches to minimize genotoxicity. Front Med 5: 356-371.

Wu X, Li Y, Crise B, Burgess SM. 2003. Transcription start regions in the human genome are favored targets for MLV integration. Science 300: 1749-1751.

Yang B, Kirby S, Lewis J, Detloff PJ, Maeda N, Smithies O. 1995. A mouse model for $\beta^{0}$-thalassemia. Proc Natl Acad Sci 92: 11608-11612.

Yannaki E, Papayannopoulou T, Jonlin E, Zervou F, Karponi G, Xagorari A, Becker P, Psatha N, Batsis I, Kaloyannidis P, et al. 2012. Hematopoietic stem cell mobilization for gene therapy of adult patients with severe $\beta$ thalassemia: Results of clinical trials using G-CSF or plerixafor in splenectomized and nonsplenectomized subjects. Mol Ther 20: 230-238.

Yu SF, von Rüden T, Kantoff PW, Garber C, Seiberg M, Rüther U, Anderson WF, Wagner EF, Gilboa E. 1986. Self-inactivating retroviral vectors designed for transfer of whole genes into mammalian cells. Proc Natl Acad Sci 83: 3194-3198. 
Development of Gene Therapy for Thalassemia

Zennou V, Petit C, Guetard D, Nerhbass U, Montagnier L, Charneau P. 2000. HIV-1 genome nuclear import is mediated by a central DNA flap. Cell 101: $173-185$.

Zhao H, Pestina TI, Nasimuzzaman M, Mehta P, Hargrove PW, Persons DA. 2009. Amelioration of murine $\beta$-thalassemia through drug selection of hematopoietic stem cells transduced with a lentiviral vector encoding both $\gamma$-globin and the MGMT drug-resistance gene. Blood 113: 5747-5756.

Zufferey R, Dull T, Mandel RJ, Bukovsky A, Quiroz D, Naldini L, Trono D. 1998. Self-inactivating lentivirus vector for safe and efficient in vivo gene delivery. J Virol 72: 9873-9880. 


\section{$\&_{\mathrm{CSH}}^{\infty} \&$ Cold Spring Harbor

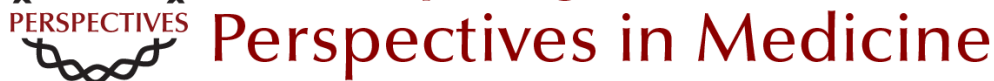

\section{Development of Gene Therapy for Thalassemia}

Arthur W. Nienhuis and Derek A. Persons

Cold Spring Harb Perspect Med 2012; doi: 10.1101/cshperspect.a011833

Subject Collection Hemoglobin and Its Diseases

The Natural History of Sickle Cell Disease Graham R. Serjeant

Current Management of Sickle Cell Anemia Patrick T. McGann, Alecia C. Nero and Russell E. Ware

Cell-Free Hemoglobin and Its Scavenger Proteins: New Disease Models Leading the Way to Targeted Therapies Dominik J. Schaer and Paul W. Buehler

Clinical Manifestations of $\alpha$-Thalassemia Elliott P. Vichinsky

Erythroid Heme Biosynthesis and Its Disorders Harry A. Dailey and Peter N. Meissner

Hemoglobin Variants: Biochemical Properties and Clinical Correlates Christopher S. Thom, Claire F. Dickson, David A. Gell, et al.

The Prevention of Thalassemia Antonio Cao and Yuet Wai Kan

The Switch from Fetal to Adult Hemoglobin Vijay G. Sankaran and Stuart H. Orkin
Transcriptional Mechanisms Underlying

Hemoglobin Synthesis

Koichi R. Katsumura, Andrew W. DeVilbiss, Nathaniel J. Pope, et al.

Iron Deficiency Anemia: A Common and Curable Disease Jeffery L. Miller

Management of the Thalassemias Nancy F. Olivieri and Gary M. Brittenham

The Molecular Basis of $\beta$-Thalassemia Swee Lay Thein

Erythropoiesis: Development and Differentiation Elaine Dzierzak and Sjaak Philipsen

Erythropoietin

H. Franklin Bunn

Classification of the Disorders of Hemoglobin Bernard G. Forget and H. Franklin Bunn

The Molecular Basis of $\alpha$-Thalassemia Douglas R. Higgs

For additional articles in this collection, see http://perspectivesinmedicine.cshlp.org/cgi/collection/ 